DOI: $10.2478 /$ lpts-2018-0037

GEOGRAPHICAL INFORMATION SYSTEMS / CARTOGRAPHY

\title{
EVALUATION OF TRANSITION TO UPDATED REGIONAL Q-GEOID MODEL
}

\author{
J. Kaminskis ${ }^{1}$, A. Vallis ${ }^{2}$, I. Stamure ${ }^{3}$, M. Reiniks ${ }^{4}$, I. Geipele ${ }^{5}$, N. Zeltins ${ }^{6}$ \\ ${ }^{1,4}$ Riga Technical University, Department of Geomatics \\ 115 - 1/1 Meza Str., Riga, LV-1048, LATVIA \\ E-mail: janis.kaminskis@rtu.lv \\ ${ }^{2}$ Ltd. Geostar, \\ 20 Marupes street, Riga, Latvia LV-1002 \\ ${ }^{3,5}$ Riga Technical University, Institute of Civil Engineering and \\ Real Estate Economics, \\ 6 - 210 Kalnciema Str., Riga, LV-1048, LATVIA \\ ${ }^{6}$ Institute of Physical Energetics \\ 11 Krivu Str., Riga, LV-1006, LATVIA
}

During the last years, the European and the Nordic quasi-geoid models and existing national q-geoid models covered the territory of Latvia. There are many ways for comparison and tests of results achieved. Scientists and professionals can compare models directly at some special geodetic co-location stations or use GNSS/ levelling sites. The results of this research can be used by scientists and specialists in the fundamental geodetic observations for independent monitoring of existing q-geoid models and evaluation of accuracy.

The research aims at evaluating the transition to the best updated regional q-geoid model. The research objectives are the following: 1) to investigate and analyse the development of q-geoid model LV14;2) to conduct precision research; 3) to assess the challenges of the European Vertical Reference System; 4) to draw conclusions that allow for further research in this area for development and improvement.

Within the framework of the research, the authors have used a variety of research methods. Historical and logical approaches, comparative analysis and synthesis methods, as well as inductive - deductive data analysis methods have been selected for the research.

A conclusion for such kind of studies is to implement the most appropriate q-geoid solution and to develop new astrogeodetic methods for unification, monitoring and for reliability of a geodetic reference network.

Keywords: accuracy evaluation, GNSS/levelling, q-geoid model 


\section{INTRODUCTION}

Now many engineering works and scientific research sectors need the accurate determination of coordinates; therefore, it is more relevant for the effective use of the Global Navigation Satellite System (GNSS) positioning technology.

All developed countries of the world have created and constantly improve land-based global and regional GNSS reference networks.

Scientific research uses the term "q-geoid", denoting the equipotential surface of the Earth's gravitational field, from which "normal height" is deducted during GNSS measurement process or some kind of innovative levelling [24].

By contrast, the term "geoid" is used, when geoid and q-geoid surface practically coincide. The Esri Support GIS Dictionary states that "geoid is a hypothetical surface representing the form the Earth's oceans would take if there were no land and the water were free to respond to the Earth's gravitational and centrifugal forces. The generated geoid is irregular, which varies from a perfect sphere by as much as 75 meters above and 100 meters below its surface" [5]. In the case of Latvia, the amplitude and precision of the output data set do not give a practical opportunity to calculate those few millimetres or centimetres that separate the geoid from q-geoid. In practice, the difference between geoid and q-geoid appears in high altitude countries, where normal height and orthometric height values by definition are distinctly different.

In 1998, a high-precision quasi-geodetic LV98 model was developed for the territory of Latvia, and its wide application in practice was started in real-time measurements and post-processing of GNSS / GPS [16]. Model LV98 is devoted to a series of research and Doctoral Theses, as well as approbated in practical geodesy. The model has been studied by specialists of different levels, who provided independently mutually consistent assessments, approving the model accuracy of $4.2 \mathrm{~cm}, 6$ $\mathrm{cm}$, and $8 \mathrm{~cm}$. The accuracy of the model to the global models, surfaces of different height reference, local support network reference points are investigated by such scientists as W. Torge, R. Forsberg, D. Solheim, A. Kalantaite, E.K. Parseliunas, P. Petroskevicius, P. Viskontas, R. Jaeger, G. Younis, A. Ellmann, L Jivall, J. Kaminskis, I. Janpaule, J. Balodis, I. Aleksejenko, M. Kalinka, etc.[1], [2], [4], [6], [8]-[15], [17], [21], [24].

The Baltic geoid is fundamentally important for the joint interconnection of the Baltic height systems. [2], [22], but each of them requires a superior geoid model. The exact geoid model is highly topical to move closer to the European Vertical Reference System (of the EVRS) requirements and needs. In Latvia, at present, the transition from the Baltic Height System (BAS-77, Kronstadt) to the system EVRS2007 (Amsterdam pale) is approaching the final stage.

The research aims at evaluating the transition process to the best updated qgeoid model in Latvia - in the Baltic Sea region. To achieve the aim of the research, the following tasks have been set: 1) to research and analyse the development of q-geoid model LV14 in Latvia; 2) to actualize the precision research in the scientific area; 3) to assess the challenges identified by the European Vertical Reference System; 4) to draw up the main conclusions that will promote the continuation of research in this field, contributing to the development and improvement. 
Within the framework of the research, the authors have used a variety of research methods. Historical and logical approaches, comparative analysis and synthesis methods, as well as inductive-deductive data analysis methods have been selected for the research.

\section{DEVELOPMENT PROCESS OF Q-GEOID MODEL LV14}

The main area of the research is the territory of Latvia. Latvia lies on the eastern shores of the Baltic Sea - on the north - western part of the East European platform. Figure 1 reflects the territory of Latvia with its geographical coordinates within the Nordic region.

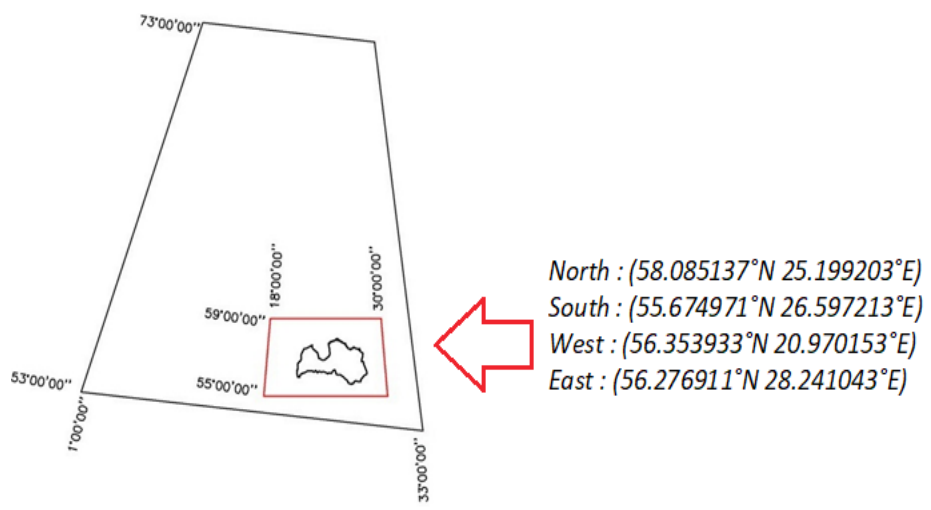

Fig. 1. Research area - the territory of Latvia in geographic coordinates [made by the authors].

Currently, the accuracy of the gravimetric geoid model LV98 in Latvia reaches 6-8 centimetres (see Fig. 2). This model is based on the use of gravimetric measurement data from the Soviet time maps and the method used in the GRAVSOFT software developed in Denmark. The developed model was a very significant achievement in the development of geodesy of Latvia, because it was the first and by 2015 the only official geoid model in Latvia.

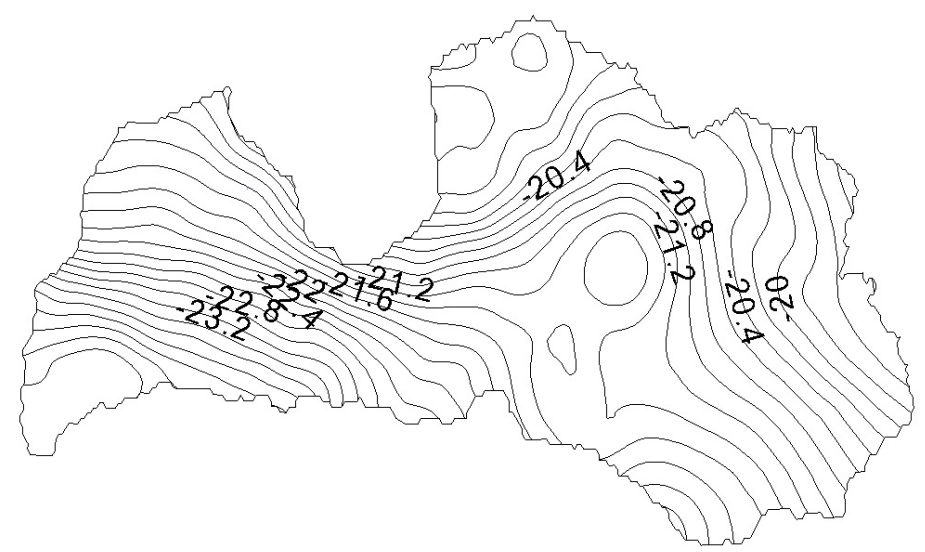

Fig. 2. Q-geoid model LV98 in Latvia. Contour interval is $0.2 \mathrm{~m}$ [made by the authors, visualised by the Trimble Business Center]. 
In the national economy of Latvia, the use of significant GNSS technological methods identifies new challenges and new precision requirements. A long period of time has passed since the establishment of LV98, and the accuracy of this geoid model is no longer in line with the precision and mass application of the GNSS measurable.

There is now a need for a more accurate geoid model operating at normal height determination, using the precision of the GNSS coordinate methods. This process demands high precision requirements of geodesy, cadastre, construction, real estate management process and other industries.

In 2012, representatives of the Geospatial Information Agency of Latvia presented the national reports providing information that to obtain a high precision levelling and GNSS measurement data Latvia would be developing a new, more accurate q-geoid model with accuracy of $1 \mathrm{~cm}$ [1]. Along with the development of a new and high-precision q-geoid model and despite the presence of the Baltic Sea, politicians of Latvia have taken a political decision to move to a new height system the European Vertical Reference System.

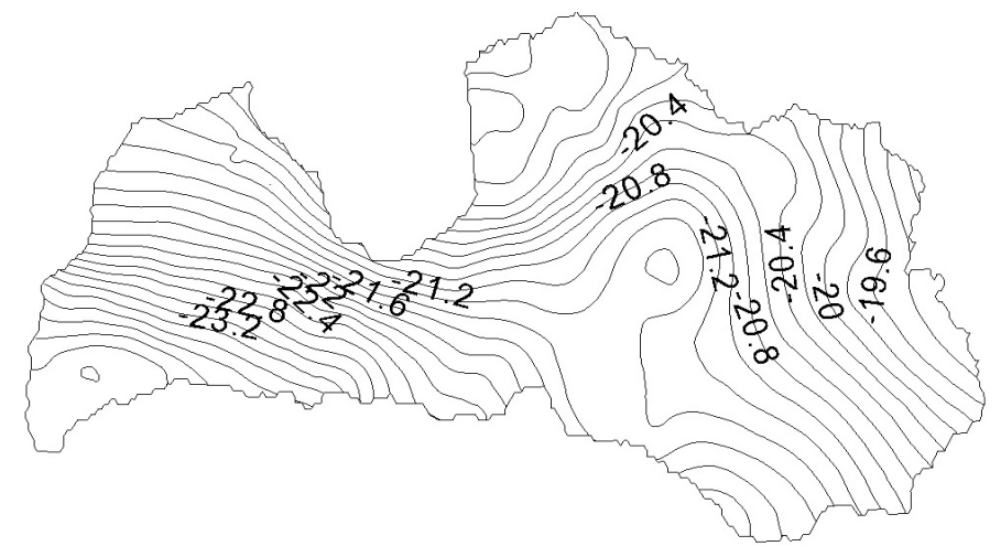

Fig. 3. Q-geoid model LV14 in Latvia. Contour interval is $0.2 \mathrm{~m}$ [made by the authors, visualised by the Trimble Business Center].

The new q-geoid model LV14 (version 1) was launched in 2014 (see Fig. 3), measuring at the accuracy of $4.5 \mathrm{~cm}$ relative to the selected GNSS and levelling different network points. Depending on the q-geoid versions and methods of measurement accuracy, assessments occur at the accuracy of $4.3 \mathrm{~cm}, 5.3 \mathrm{~cm}$ and $6.6 \mathrm{~cm}$. The model was designed as a checklist with irregular step length and width, close to 0.025 degrees. To develop the model, fixed points of up to $2 \mathrm{~km}$ behind the state border of Latvia were used.

However, after a few days the new model (version 2) was launched in the form of a regular matrix with a regular step both in length and width of 0.025 degrees. Both specified in the model LV14 versions (version 1 and version 2) cannot be used in the state sea aquarium and several places in the border area.

A short time later a rebuilt model (version 3) was launched, which covered a wider land area of Latvia ( $6 \mathrm{~km}$ beyond the border) and it was used all over the land area in Latvia. 


\section{Q-GEOID PATTERNS FOR ACCURACY RESEARCH}

In the scientific environment, no publications have been published on the developed version of the LV14 model, there is no evidence or independently conducted tests and studies of data and methodology used for calculations. Based on the above, the authors of the research compared the different versions of the LV14 model with the previously widely used q-geoid model LV98 and the publicly available latest qgeoid models of other countries, which also include the territories of other Baltic Sea countries - Estonia, Lithuania and Sweden.

The comparison was made on the surface of the ellipsoid. Originally, it was established in point grille, which coincided with the height of the surface of a rotating ellipsoid. Trimble Business Center (version 3.40) allows its users to effectively edit, process and configure geospatial data and create accurate reports. By using different models, "normal heights" were obtained, which were further used to calculate the difference between these indicators using the spreadsheet data. The visualization of the received data was implemented with the help of Trimble Business Center.

To evaluate the accuracy of the new q-geoid model, it was compared with the model LV98, and this comparison gave a cartogram with several places in Latvia, where are observed visually a significant differences. Extremes were identified from $-2 \mathrm{~cm}$ in the north of Vidzeme up to $+43 \mathrm{~cm}$ in Kurzeme (see Fig.4).

Table 1

Differences between the Compared Models LV98 and LV14 [made by the authors]

\begin{tabular}{|l|c|c|c|c|}
\hline Compared models & $\begin{array}{c}\text { MEAN } \\
(\mathrm{m})\end{array}$ & $\begin{array}{c}\text { RMS } \\
(\mathrm{m})\end{array}$ & $\begin{array}{c}\text { MIN } \\
(\mathrm{m})\end{array}$ & $\begin{array}{c}\text { MAX } \\
(\mathrm{m})\end{array}$ \\
\hline LV98 and LV14 (version 3) & 0.142 & 0.058 & -0.020 & 0.432 \\
\hline
\end{tabular}

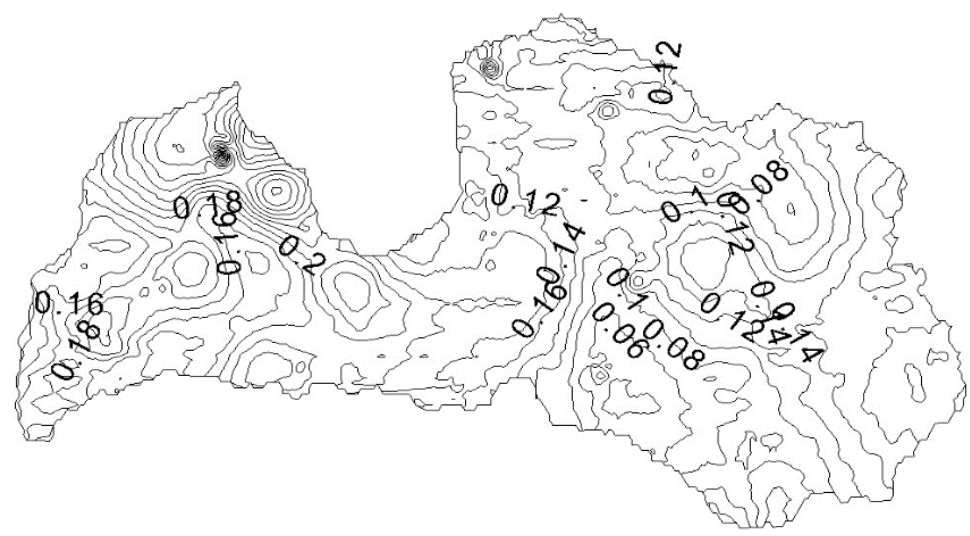

Fig. 4. Differences between q-geoid model LV98 and LV14 (version 3) in Latvia. Contour interval is $0.2 \mathrm{~m}$ [made by the authors, visualised by the Trimble Business Center].

By comparing LV14 model version 3 with Sweden SWEN08_2000 q-geoid model, several significant differences can be identified (see Fig.5). Swedish highprecision q-geoid model covers the western part of the territory of Latvia and a bit of Vidzeme. 
Differences between the Compared Models SWEN08_2000 and LV14 [made by the authors]

\begin{tabular}{|l|c|c|c|c|}
\hline Compared models & $\begin{array}{c}\text { MEAN } \\
(\mathrm{m})\end{array}$ & $\begin{array}{c}\text { RMS } \\
(\mathrm{m})\end{array}$ & $\begin{array}{c}\text { MIN } \\
(\mathrm{m})\end{array}$ & $\begin{array}{c}\text { MAX } \\
(\mathrm{m})\end{array}$ \\
\hline SWEN08_2000 and LV14 (version 3) & -0.069 & 0.032 & -0.176 & 0.090 \\
\hline
\end{tabular}

The standard error of Swedish q-geoid SWEN08_RH2000 was estimated to be 10-15 millimetres everywhere on the Swedish mainland with exception of the small area to the north-west. The standard error is larger in the latter area and at sea, probably around 5-10 centimetres [19].

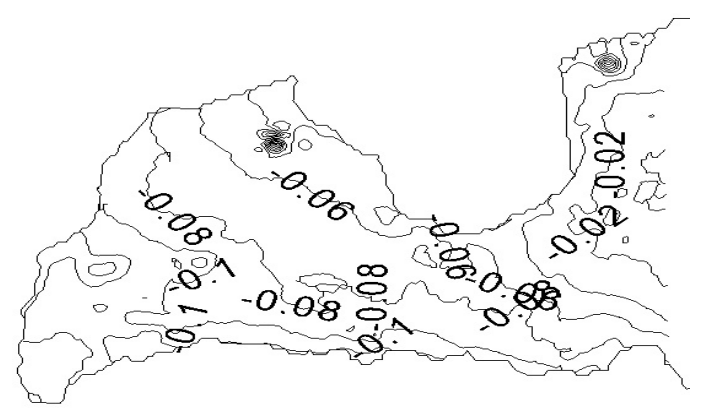

Fig. 5. Differences between q-geoid model SWEN08_2000 and LV14 (version 3) in Latvia. Contour interval is $0.2 \mathrm{~m}$ [made by the authors, visualised by the Trimble Business Center].

LV14 model version 3 was compared with the Estonian q-geoid model EST GEOID2003 (see Fig. 6), which was assessed at the accuracy of 1-3 cm [20]. In addition, compared to the Swedish q-geoid model several significant differences can be identified: the Estonian precision q-geoid model covers the territory of Latvia in the northern part of Vidzeme, Latgale and a bit of Kurzeme.

Table 3

Differences between the Compared Models EST_GEOID2003 and LV14 [made by the authors]

\begin{tabular}{|l|c|c|c|c|}
\hline Compared models & $\begin{array}{c}\text { MEAN } \\
(\mathrm{m})\end{array}$ & $\begin{array}{c}\text { RMS } \\
(\mathrm{m})\end{array}$ & $\begin{array}{c}\text { MIN } \\
(\mathrm{m})\end{array}$ & $\begin{array}{c}\text { MAX } \\
(\mathrm{m})\end{array}$ \\
\hline EST_GEOID2003 and LV14 (version 3) & 0.115 & 0.034 & -0.009 & 0.276 \\
\hline
\end{tabular}

Graphically marked problem areas were compared in Vidzeme and Kurzeme. It is important to note that the Estonian q-geoid model EST_GEOID2003 has been calculated to include the latest GNSS and levelling measurement data.
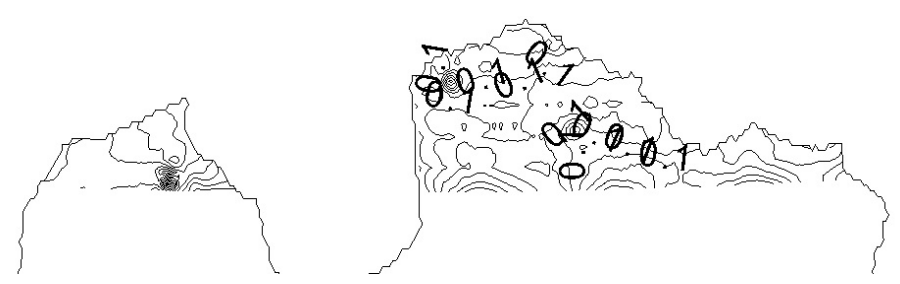

Fig. 6. Differences between q-geoid model EST_GEOID2003 and LV14 (version 3) in Latvia. Contour interval is $0.2 \mathrm{~m}$ [made by the authors, visualised by the Trimble Business Center]. 
LV14 model version 3 was compared with the Lithuanian q-geoid LITH2011 model that had been created at the same time as LV98 model and it was also assessed at the accuracy of 6-8 $\mathrm{cm}$ (see Fig.7).

Table 4

Differences between the Compared Models LITH2011 and LV14 [made by the authors]

\begin{tabular}{|l|c|c|c|c|}
\hline Compared models & $\begin{array}{c}\text { MEAN } \\
(\mathrm{m})\end{array}$ & $\begin{array}{c}\text { RMS } \\
(\mathrm{m})\end{array}$ & $\begin{array}{c}\text { MIN } \\
(\mathrm{m})\end{array}$ & $\begin{array}{c}\text { MAX } \\
(\mathrm{m})\end{array}$ \\
\hline LITH2011 and LV14 (version 3) & -0.008 & 0.033 & -0.09 & 0.079 \\
\hline
\end{tabular}

The Lithuanian q-geoid model covers the southern part of the territory of Latvia to Riga.

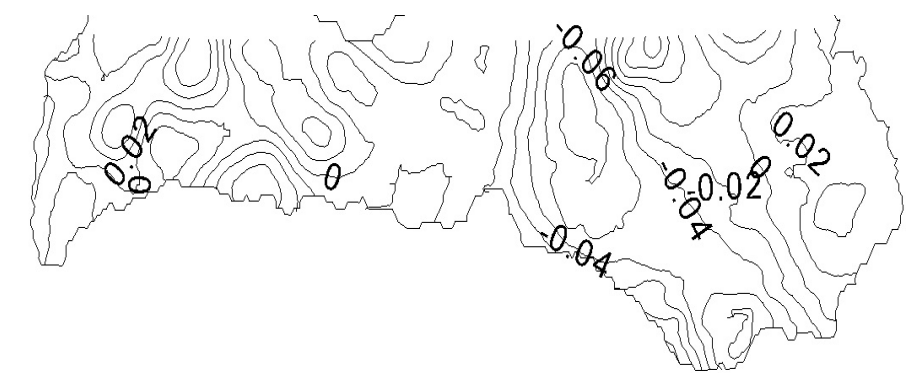

Fig. 7. Differences between q-geoid model LITH2011 and LV14 (version 3) in Latvia. Contour interval is $0.2 \mathrm{~m}$ [made by the authors, visualised by the Trimble Business Center].

In 2014, geodetic specialists of Estonia pointed out significant failures on the ground carried out by gravimetric measurement data within the framework of the scientific research into the development on a high surface [20]. By contrast, the only publicly available information, which gives an idea of the creation of LV14 different versions of q-geoid model and data used, is a gravimetric anomaly map of the territory of Latvia in 2014 [1]. Comparing and analysing Figs. 6 and 7, it can be concluded that according to scientists from Estonia, the new model is indicating false and incomplete data.

\section{THE TRANSITION TO THE EUROPEAN VERTICAL REFERENCE SYSTEM}

Due to a political decision taken to move from the BAS-77 height reference system to a height reference system of EVRS, implementation of LAS-2000.5 was carried out, which was designed for a theoretical transition algorithm [23]. A graphical representation of this algorithm is close to a linear transition from $12 \mathrm{~cm}$ near Daugavpils up to $17 \mathrm{~cm}$ near Ventspils (see Fig. 8).

Scientists have discovered that during the transition to a new height system (LAS-2000.5), the height of the highest mountain in Latvia - Gaizinkalns - has been significantly increased during the process of data conversion. Previously, the height of Gaiziňš, according to the Baltic Height System (BAS-77), was 311.495 m, now $311.94 \mathrm{~m}$ above the sea level. 


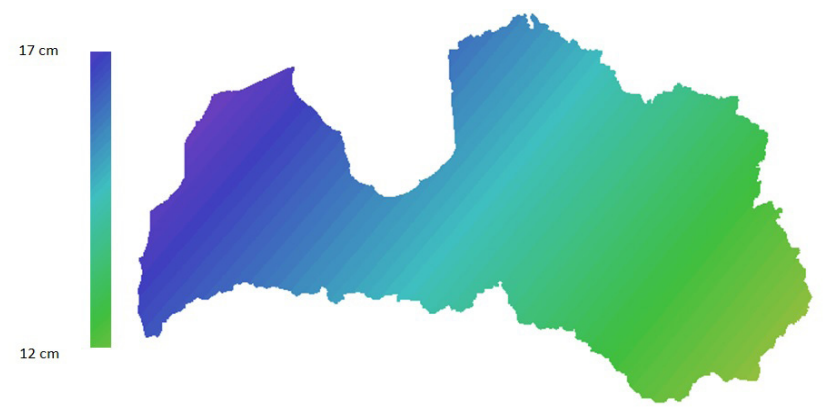

Fig. 8. Data conversion algorithm from BAS-77 to LAS-2000.5 [made by the authors, visualised by the Trimble Business Center].

Highly detailed topographic information (ADTI) is mainly generated based on the heights obtained by the GNSS/GPS measurement methods using LV98 q-geoid model, while the transition algorithm does not include LV98 model. Consequently, the ADTI data introduce errors, well above the height of certainty of ADTI data. ADTI data introduce errors from $-13 \mathrm{~cm}$ in Vidzeme to $+26 \mathrm{~cm}$ in Kurzeme (see Fig. 9).

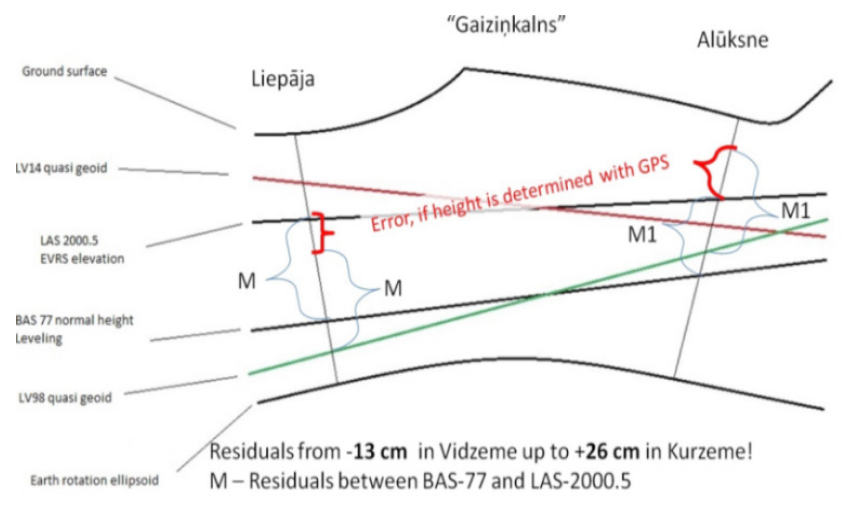

Fig. 9. Transformation algorithm errors of the highly detailed topographical data [made by the authors].

Developing ADTI data transformation algorithm, it is highly important to take into account that this type of elevation conversion does not respect the main data generation surfaces used for elevation calculations.

LV14 q-geoid model version 4 is available with the altered values and specialists' recommendations, but still there are minor bug fixes.

Differences between the Compared Models EGM-2008 and

LV14 (version 3 and version 4) [made by the authors]

\begin{tabular}{|l|l|l|l|l|}
\hline Compared models & $\begin{array}{l}\text { MEAN } \\
(\mathrm{m})\end{array}$ & $\begin{array}{l}\text { RMS } \\
(\mathrm{m})\end{array}$ & $\begin{array}{l}\text { MIN } \\
(\mathrm{m})\end{array}$ & $\begin{array}{l}\text { MAX } \\
(\mathrm{m})\end{array}$ \\
\hline EGM-2008 and LV14 (version 3) & -0.031 & 0.034 & -0.214 & 0.094 \\
\hline EGM-2008 and LV14 (version 4) & -0.031 & 0.032 & -0.124 & 0.050 \\
\hline
\end{tabular}


To determine compliance with the latest European q-geoid model that is related to the height reference system of EVRS, the comparison was made with the latest and the best q-geoid model EGG 2008 (see Fig. 10).
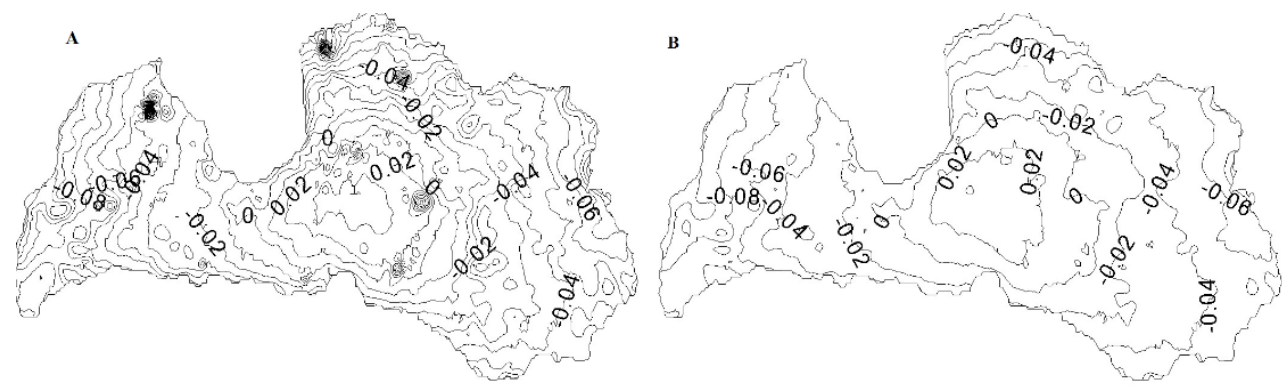

Fig. 10. Differences between q-geoid model EGM-2008 and LV14 A (version 3) and B (version 4) in Latvia. Contour interval is $0.2 \mathrm{~m}$ [made by the authors, visualised by the Trimble Business Center].

Analysing information in Version 3 and Version 4, it can be concluded that substantial errors are no longer visible in the model; however, there are still some problem areas, which would require more research and in-depth analysis.

\section{CONCLUSIONS}

Within the framework of the research, the authors have come to the following main conclusions, which will allow for further research in this area, including digital zenith camera measurements for the deflection of the vertical [17], [18]:

1. Transformation algorithm used for highly detailed topographic information or ADTI data elevation conversion does not respect the main surfaces used for elevation data generation (such as LV98).

2. Evaluating gravimetric anomalies defined in the report by the Geospatial Information Agency of Latvia on 14 November 2014 and comparing them with the Estonian report by NKG Assembly 2014 "Investigations towards the NKG2014 Geoid Model in Estonia" [20], it is clearly visible that the latest Q-geoid model LV14 contains or includes coarse gravimetric errors.

3. After transition to EVRS, in the national legislation there will still be both elevation reference surfaces - q-geoid LV98 (BAS-77/Kronstadt in the Baltic) and q-geoid LV14 (LAS2000.5/N.A.P., Amsterdam) -, and both will not have a correct transition algorithm for practitioners. The authors of the research conclude that the transition to EVRS is done in isolation from real needs and is poorly prepared.

4. Version 4 of LV14 Q-geoid model is consistent with EVRS in the range of $16 \mathrm{~cm}$ and it raises doubts about the effectiveness and usefulness of the elevation reference system transition.

5. Due to the implementation of a new height reference system (LAS2000.5), the value for the highest Latvian mountain "Gaizinkalns" also considerably grew; it was $311.495 \mathrm{~m}$, now $-311.94 \mathrm{~m}$ above the sea level. 


\section{REFERENCES}

1. Aleksejenko, I., \& Kosenko K. (2012). National Report of Latvia. NKG Working Group on Geoid and Height System, Latvian Geospatial Information Agency. Retrieved from http://www.nkg.fi/nkg/sites/default/files/WGGHS2012_NKG_Geoid_Heght_KKosenko.pdf.

2. Aleksejenko, I., Sakne, J., Kalinka, M., Reiniks, M., Krikstaponis, B., Parseliunas, E.K., Petroskevicius, P., \& Viskontas, P. (2012). The united geodetic vertical network of Latvia and Lithuania. Geodesy and Cartography, 38(1), 9-19.

3. Ellmann, A. (2012). Considerations on the further improvements of regional geoid modelling over the Baltic countries. Geodezija ir Kartografija, 36(1), 5-15.

4. Ellmann, A. (2004). The geoid for the Baltic countries determined by the least squares modification of Stoke's formula. Doctoral Dissertation in Geodesy. Stocholm: Royal Institute of Technology (KTH), Department of Infrastructure.

5. Esri Support GIS Dictionary. (2017). Definition of geoid. Retrieved from https://support. esri.com/en/other-resources/gis-dictionary/term/geoid

6. Forsberg, R., Kaminskis, J., \& Solheim, D. (1997). Geoid of the Nordic and Baltic Region from gravimetry and satellite altimetry. In J. Segawa, H. Fujimoto\& S. Okubo (Eds.), Gravity, geoid and marine geodesy. (pp. 540-547). IAG Symp. Series, 117, Berlin: Springer.

7. International Centre for Global Earth Models. Retrieved from http://icgem.gfz-potsdam. de/ICGEM

8. Jäger, R., Kaminskis, J., Strauhmanis, J., \& Younis, G. (2012). Determination of quasigeoid as height component of the geodetic infrastructure for GNSS positioning services in the Baltic States. Latvian Journal of Physics and Technical Sciences, 3, 5-15.

9. Janpaule, I., Jaeger, R., Younis, G., Kaminskis, J., \& Zariņš, A. (2013). DFHRS-based computation of quasi-geoid of Latvia. Geodesy and Cartography, 39(1), 11-17. ISSN 2029-6991.

10. Janpaule, I. (2014). Latvijas geoōda modeḷa precizitātes uzlabošanas iespējas. [Latvian geoid model's accuracy improvement opportunities]. In 72nd Scientific Conference of the University of Latvia, Astronomy and Geodesy Section, 5 February 2014, Latvia.

11. Jivall, L., Kaminskis, J., \& Parseliunas, E. (2008). Improvement and extension of ETRS 89 in Latvia and Lithuania based on the NKG 2003 GPS campaign. EUREF Publication No.16 (Band 40), (pp. 156-162), Frankfurt am Main.

12. Jürgenson, H. (2002). Estonian geoid and other reference surfaces. Geodezija ir Kartografija, 28(3), 108-111.

13. Jürgenson, H., Türk, K., \& Randjärv, J. (2011). Determination and evaluation of the Estonian fitted geoid model EST-GEOID 2003. Geodesy and Cartography, 37(1), 15-21.

14. Kaminskis, J. (2009). Apvienotais Latvijas gravimetriskais geoīds [Joint gravimetric geoid of Latvia]. Geomatics, 5, 13-20.

15. Kaminskis, J. (2010). Geoid model for surveying in Latvia. In International FIG Congress "Facing the Challenges - Building the Capacity", 10-16 April 2010 (pp. 1-7). Australia, Sidney.

16. Kaminskis, J. (2010). Geoid model in Latvia and its development. PhD Thesis. Riga: RTU. ISBN 978-9934-507-27-4

17. Kaminskis, J., Janpaule, I., Zarins, A., \& Rothacher, M. (2016). Latvian digital zenith camera in test applications. In Proceedings of NKG 2014 General Assembly, 1-4 September 2014 (pp. 122-125). Gothenburg, Sweden, ISSN 0280-5731.

18. Kaminskis, J., Vallis, A., Geipele, I., Stamure, I., Reiniks, M., \& Krutova, U. (2017). Evaluation of the updated regional transition Q-geoid model. In EUREF Symposia 2017, 17-19 May 2017. Wroclaw. Retrieved from http://www.euref.eu/symposia/2017Wroclaw/0211-Kaminskis.pdf 
19. Lantmäteriet, SWEN08_RH2000 \& SWEN08_RH70. (2016). Retrieved from https:// www.lantmateriet.se/en/Maps-and-geographic-information/GPS-and-geodetic-surveys/ Geodesy/ Transformations/ Geoid-models/

20. Märdla, S. Oja, T., \& Ellmann, A. (2014). Investigations towards the NKG2014 geoid model in Estonia. Abstract Book for the NKG General Assembly. Retrieved from https:// www.lantmateriet.se/globalassets/kartor-och-geografisk-information/gps-och-matning/ geodesi/rapporter_publikationer/rapporter/lantmaterirapport-2016-4-nkg-general-assembly-2014.pdf

21. Petroškevičius, P., \& Paršeliūnas, E. (1995). Determination of the Lithuanian territory geoid. Geodezija ir Kartografija, 21(2), 50-58.

22. Sas-Uhrynowski, A., Mroczek, S., Sas, A., Petroškevičius, P., Obuchowski, R., \& Rimkus, D. (2002). Establishment of Lithuanian national gravimetric first order network. Geodezija ir Kartografija,28(3), 75-82.

23. Sproǵis, V., \& Aleksejenko, I., (2014). Q-geoid model LV'14. Latvian Geospatial Information Agency. Retrieved from http://www.lgia.gov.lv/ /media/LGIA/Aktual14/ Kvazogeoida_modelis_LV14_22112014.ashx

24. Torge, W. (2001). Geodesy (3rd ed.). Berlin, New York: Walter de Gruyter.

\title{
KVAZIG̣EOĪDA REG̣IONĀLĀ MODEḶA PILNVEIDOŠANAS PROCEŚA NOVĒRTĒJUMS LATVIJĀ
}

\author{
J. Kaminskis, A. Vallis, I. Stāmure, M. Reiniks, I. Geipele, N. Zeltiṇš
}

K ops avi $1 \mathrm{ku} \mathrm{m} \mathrm{s}$

Mūsdienās liela nozīme ir globālās navigācijas satelītu sistēmas pozicionēšanas tehnoloǵiju racionālai un lietderīgai izmantošanai dažādās zinātnisko pētījumu un inženiertehnisko darbu jomās, kur nepieciešama precīzu pozīciju noteikšana, piemēram, nekustamā īpašuma robežu noteikšanai, kadastra datu iegūšanai, būvniecības procesu realizācijai, arī jaunu teritoriju plānojuma attīstībai, u.c. Daudzās pasaules valstīs ir izveidoti, tiek pastāvīgi uzlaboti, kā arī pilnveidoti augstas precizitātes, uz zemes bāzētie globālie un reǵionālie globālās navigācijas satelītu sistēmas pastāvīgās darbības atbalsta sistēmu tīkli.

Pētījuma mērḳis ir novērtēt uz uzlabotu kvaziǵeoīda reǵionālo modeli vērstu pārejas procesu. Pētījuma mērķa sasniegšanai nepieciešams izpētīt un analizēt kvaziǵeoīda modeḷa LV14 attīstību, izvērtēt esošos precizitātes pētījumus, novērtēt Eiropas vertikālās atskaites sistēmas ieviešanas problemātiku un izstrādāt galvenos secinājumus un attīstības priekšlikumus nākotnes pêtījumu virzienu attīstībai un uzlabošanai kvaziǵeoīda reǵionālā modeḷa pilnveidošanai Latvijā, t.sk. pielietojot inovatīvus astro-ǵeodēziskos novērojumus.

Pêtījuma izstrādes laikā ir izvēlēta vēsturiskā un log̣iskā pieeja, salīdzinošā analīze un sintēzes metodes, kā arī induktīvās-deduktīvās datu analīzes metodes. Datu apstrādei un informācijas vizualizācijai izmantota Trimble Business Center programmatūra.

16.03.2018. 